\title{
Contents, Vol. 48, 1985
}

\section{No. 1 Original Paper}

Nonmigrating Rhythmic Activity in the Stomach and Duodenum of Neonates

Tomomasa, T.; Itoh, Z.; Koizumi, T.; Kuroume, T 1

Small Intestine Transit Time and Lactose Absorption during Phototherapy

Sivan, Y.; Dinari, G.; Goodman, C; Merlob, P.; Nitzan, M 10

Polymorphonuclear Leukocyte Function in Term and Preterm Newborn Infants

Gahr, M.; Blanke, R.; Speer, C.P 15

Sequestration of 3H-Vitamin D3 by the Fetal and Neonatal Rat Liver

Martial, J.; Plourde, V.; Gascon-Barré, M 21

Effects of Oral Caffeine Intubation on Bones in Protein-Energy Malnourished Newborn Rats

Batirbaygil, Y.; Quinby, G.E., Jr.; Nakamoto, T 29

Starvation-Induced Organ Hypoplasia in Prenatal and Postnatal Guinea Pigs

Lechner, A.J 36

Changes in Plasma Arginine Vasopressin during Transition from Fetus to Newborn following

Minimal Trauma Delivery of Lambs and Goats

LefПer, C.W.; Crofton, J.; Brooks, D.P.; Share, L.; Hessler, J.R.; Green, R.S 43

Protection by Magnesium of Renal Calcinosis in Furosemide-Treated Weanling Rats with

Moderate Magnesium Deficiency

Caddell, J.L 49

Influence of Gliadin on Fetal Chick Intestine in Tissue Culture

Mothes, T.; Mühle, W.; Müller, F.; Hekkens, W.T.J.M 59

Announcement 48

No. 2 Original Paper

Plasma Six-Keto-Prostaglandin F! $\alpha$ and Endocrine Pancreatic Function in the Newborn Infant of the Diabetic Mother

Kääpä, P.; Knip, M.; Viinikka, L.; Ylikorkala, $0 \quad 65$

Postnatal Changes in Fetal Hemoglobin, Oxygen Affinity and 2,3-Diphosphoglycerate in Previously Transfused Preterm Infants

Brown, M.S.; Phipps, R.H.; Dallman, P.R 70

Carnitine and Carnitine Transferases in the Intestinal Mucosa of Suckling Rats

Hahn, P.; Chanez, C; Hamilton, J 77

Relationship between Resting Glucose Consumption and Insulin Secretion in the Ovine

Fetus

Philipps, A.F.; Porte, P.W.; Raye, J.R

\section{Contents}

Effects of Fasting on Glucose Turnover Rate and Metabolite Levels in Conscious Pregnant

Guinea Pigs

Gilbert, M.; Sparks, J.W.; Girard, J.; Battaglia, F.C 90

Autoregulation of Cerebral Blood Flow in the Newborn Beagle Puppy 
Pasternak, J.F.; Groothuis, D.R

100

Effect of Digitoxin on Vaginal Epithelial Differentiation in the Balb/c Mouse

Gorwill, R.H.; Steele, H.D 110

Placental Handling of Zinc in the Guinea Pig

Simmer, K.; Dwight, J.S.J.; Brown, I.M.H.; Thompson, R.P.H.; Young, M 114

Brief Communication

Evaluation in Guinea Pigs of the Allergenic Capacity of Two Infant Formulae Based on

Hydrolyzed Milk Proteins

Granati, B.; Marioni, L.; Rubaltelli, F.F 122

No. 3 Original Paper

Effects of Intrauterine Nutritional Supplementation on Fetal Growth Retardation

Charlton, V.; Johengen, M 125

Clearance of Compounds of Different Molecular Size in the Human Placenta in vitro

Challier, J.C.; Guerre-Millo, M.; Nandakumaran, M.; Gerbaut, L.; d'Athis, Ph 143

Effect of Rapid-Rate Ventilation on the Experimental Diseased Lung Caused by Meconium

Aspiration

Obara, H.; Maekawa, N.; Hamatani, S.; Iwai, S

Development of Sexual Dimorphism in Human Urogenital Sinus Complex

Kellokumpu-Lehtinen, P 157

Carbonic Anhydrase in the Metanephrogenic Zone of the Human Fetal Kidney

Larsson, L.; Lönnerholm, G 168

Effects of Cyclosporin A on Fetal Development in the Rat

Brown, P.A.J.; Gray, E.S.; Whiting, P.H.; Simpson, J.G.; Thomson, A.W 172

No. 4 Perinatal Endocrinology and Metabolism

Hormonal and Metabolic Changes in the Perinatal Period

Mayor, F.; Cuezva, J.M 185

Decreased Uterine Blood Flow in the Diabetic Pregnant Rat Does Not Modify the Augmented

Glucose Transfer to the Fetus

Palacín, M.; Lasunción, M.A.; Martin, A.; Herrera, E

Insulin and Glucagon during the Perinatal Period: Secretion and Metabolic Effects on the

Liver

Ktorza, A.; Bihoreau, M.-T.; Nurjhan, N.; Picon, L.; Girard, J. 204

Effect of Glucose and Insulin Administration on Hepatic Adenylate Energy Charge and the

Cytosolic Redox State in the Neonates of Normal and Insulin-Treated Diabetic Rats

Cuezva, J.M.; Patel, M.S 221

Influence of Hormones and Undernutrition on Brain Development in Newborn Rats

Pascual-Leone, A.M.; Escrivá, F.; Alvarez, C; Goya, L.; Rodriguez, C 228

The Role of Lactate as an Energy Substrate for the Brain during the Early Neonatal Period

Medina, J.M 237

Contribution of Brown Fat to the Neonatal Thermogenesis

Benito, M 245

Contents V

Gamma-Glutamyl-Amino Acids as Signals for the Hormonal Regulation of Amino Acid

Uptake by the Mammary Gland of the Lactating Rat

Vina, J.R.; Puertes, I.R.; Montoro, J.B.; Saez, G.T.; Vina, J 250

No. 5 Original Paper 
Comparison of the Metabolic Activities of Enterocytes Isolated from Different Regions of the Small Intestine of the Neonate

Mackenzie, N.M 257

Prenatal versus Neonatal Long-Term Effect of Phenobarbital on Mouse Microsomal Drug-

Oxidizing System

Yanai, J.; Wanich, A 269

Vitamin D3 3ß Sulfate Has Less Biological Activity than Free Vitamin D3 during Pregnancy in Rats

Cancela, L.; Marie, P.J.; Le Boulch, N.; Miravet, L 274

Effects of Corticosteroids and Pancreatic Hormones on Carbamyl Phosphate Synthetase-I

and Ornithine Transcarbamylase Activities in Fetal Rat Liver

Gautier, C; Habechi, Z.; Belbekouche, M.; Vaillant, R 285

Renal Prostaglandin E2 Synthesis and Degradation in the Developing Rat

Moel, D.I.; Cohn, R.A.; Penning, J 292

Incorporation of Linoleic and Arachidonic Acids into Ovine Placental Phospholipids in vitro

Shand, J.H.; Noble, R.C 299

Observations on the Development of the Febrile Response to Pyrogen in Newborn Pigs

Moraes, R.N.; Macari, M.; Pelá, I.R 307

No. 6 Review

Plasma Calcium Control in the Rat Fetus Chalon, S.; Garel, J.-M.

I. Influence of Maternal Hormones 313

II. Influence of Fetal Hormones 323

III. Influence of Alterations in Maternal Plasma Calcium on Fetal Plasma Calcium Level 329

Original Paper

Photodynamic Damage Induced by Bilirubin on Human Platelets: Possible Relevance to

Newborn Pathology

Tozzi-Ciancarelli, M.G.; Amicosante, G.; Menichelli, A.; Di Giulio, S.; Del Principe, D. 336

Reevaluation of Thyroid Function in Low Birth Weight Infants Based on Free Triiodothyronine and Triiodothyronine

Nagashima, K.; Onoda, K.; Suzuki, S.; Sakaguchi, M.; Kuroume, T341

Levels of Total and Free Tryptophan in Maternal and in Umbilical Blood of Infants Born by Vaginal Delivery and by Elective Cesarean Section

Zanardo, V.; Casson, L.; Costa, C; Biasiolo, M.; Allegri, G.; Vicenti, E.; Grella, P. . . 346

Hepatic Metabolism of Orally Administered Prostaglandin F2 $\alpha$ in Suckling and Weanling

Rats

Bedrick, A.D.; Koldovský, 0351

Bronchiolar Epithelial Lesions in Spontaneously Breathing Premature Newborn Rabbits

Nilsson, R.; Robertson, B 357

VI Contents

Brief Communication

Distribution of Zinc and Copper in Maternal and Cord Blood at Delivery

Yamashita, K.; Ohno, H.; Doi, R.; Mure, K.; Ishikawa, M.; Shimizu, T.; Arai, K.;

Taniguchi, N 362

Abstracts 
Abstracts from the Meeting 'Neonatal Therapy: An Update'. Abano Terme (Italy), Septem ber 13-14, 1985 366

Author Index Subject Index

375377 